\title{
Depositional architecture and sequence stratigraphy of Pleistocene coarse-grained deltas along the Ligurian coast (Italy)
}

\author{
A Ciampalini ${ }^{1, *}$ and M Firpo $^{2}$ \\ ${ }^{1}$ Earth Sciences Department, Università di Firenze, Via La Pira 4, Firenze, Italy. \\ ${ }^{2}$ Dipartimento di Scienze della Terra, dell'Ambiente e della Vita, Università di Genova, \\ Corso Europa 26, Genova, Italy. \\ ${ }^{*}$ Corresponding author.e-mail: andrea.ciampalini@unifi.it
}

This study aims to develop a better understanding of the stratigraphy of the southern side of the Maritime Alps and of the Ligurian Sea during the Plio-Pleistocene. Five stratigraphic sections were measured and studied in the Segno River valley (Liguria, Italy). These sections are composed of Lower to Middle Pleistocene marine and continental deposits. Based on detailed mapping and sedimentological analysis, 12 marine and deltaic facies were identified. These facies were grouped into facies associations. Two allostratigraphic units were recognized, namely U1 and U2 from oldest to youngest. The lower unit (U1) represents the evolution of a coarse-grained delta developed in a valley or embayment. Within the deltaic sequence, transgressive and highstand systems tracts were recognized. The coarsening/shallowing upward trend observed within the sections suggests that the delta prograded rapidly in the landward portion of the canyon adjacent to the paleo-river outlet. The upper boundary of U1 is represented by a subaerial unconformity overlain by U2, which is composed of sediments deposited by several alluvial fan systems.

\section{Introduction}

Coastal marine depositional systems, and in particular, deltas are useful to determine changes in relative sea-level as the result of the interplay between tectonics, eustasy, climate, basin physiography and sediment supply. Ancient alluvial coarse-grained deltas have been intensively studied in many areas (Bardaji et al. 1990; Lopez-Blanco et al. 2003; Breda et al. 2007; Di Celma and Cantalamessa 2007; Ozel et al. 2007; Sáez et al. 2007; Longhitano 2008; Backert et al. 2010; Di Celma et al. 2010; Fidolini et al. 2013). The identification of each depositional environment within the deltaic system (delta plain, delta front, delta slope and offshore-transition) and their sedimentological characteristics is necessary for the reconstruction of the evolution of the delta and the stacking pattern of these various elements are necessary for the interpretation of the influence of tectonics and eustasy. Along the Mediterranean, and in particular the Italian coasts, deltaic sediments have been intensively studied to understand the interplay between tectonics and eustasy during the Plio-Pleistocene (e.g., Cantalamessa and Di Celma 2004). These deposits are well studied along the coasts of the Tyrrhenian Sea, but they have been less studied along the Ligurian Sea. In this work, detailed sedimentological and high resolution sequence stratigraphic analysis of a Lower to Middle Pleistocene deltaic sequence overlain by Middle Pleistocene alluvial fan and fluvial deposits from

Keywords. Facies analysis; Pleistocene; Liguria; Gilbert-type delta; allostratigraphic unit.

J. Earth Syst. Sci. 124, No. 8, December 2015, pp. 1765-1780

(C) Indian Academy of Sciences 
western Liguria is presented. This paper is focussed on the characterization of the deltaic Lower to Middle Pleistocene deposits (U1) which have not been previously recognized along this coast. The goal of this study is to contribute to the evaluation of the interplay between tectonics, eustasy and sediment supply of the western Ligurian margin.

\section{Geological setting}

\subsection{Ligurian Alps}

The Ligurian Alps are the SW segment of the Alpine orogen in the NW Italian peninsula. The building of the Ligurian Alps took place due to the subduction of the Jurassic passive margin of the Ligurian Ocean. The subsequent phase of continental collision between Africa and Europe (Vanossi et al. 1984) caused subduction of slices of oceanic and continental crusts. During the Oligocene, the Ligurian Alps were already exhumed, forming relatively high topography. They became part of the passive continental margin of the LigurianProvençal basin created during the counterclockwise rotation of the Corsica-Sardinian block from the European margin to its present position, which was reached by around $16 \mathrm{Ma}$ (Doglioni et al. 1997; Rollet et al. 2002). Since then, the extensional regime has been migrating eastward, causing the opening of the Tyrrhenian Sea. The Neogene to present tectonic evolution of the western Alpine Arc and the Ligurian Alps is characterized by the change from collision to post-collisional extension (Sue and Tricart 2002; Champagnac et al. 2004). Within this dynamic setting, the Ligurian Alps occupy a pivotal position as they represent the link zone between the Alps and Apennine ranges.

\subsection{The post-orogenic succession}

The post-Miocene evolution of the Vado Ligure Basin started when erosion of the southern side of the Ligurian Alps formed submarine canyons, today submerged, along the Ligurian coast. The opening of the Gibraltair strait $(\sim 5.3 \mathrm{Ma})$ caused a major transgression in the Mediterranean. The transition between Miocene and Pliocene is marked by several features; at the margin of the depressions within the Mediterranean Sea, an angular unconformity, dipping towards the rim of the basin, is present, whereas in the depocentres a gradual, conformable transition from Messinian marine clays to Mio-Pliocene brackish to freshwater clay (Colalongo and Sartoni 1979) to Lower Pliocene marine clays can be found (Bossio et al. 1993). From $23.6 \mathrm{Ma}$ to the Calabrian (Gibbard and Head 2009), a long-term normal regression took place (Ambrosetti et al. 1979). Well-defined coarsening upward sequences show a transition from intensely bioturbated, fossiliferous, marine clay, grading into fossiliferous sandy shore and beach deposits, in turn overlain by lagoonal organic-rich muds and channelized fluvial sands and gravels. Along the Ligurian coast, the Pliocene deposits crop out in several separate strips between Genova and Ventimiglia (figure 1). These strips represent usually E-W or N-S oriented neostructural depressions which were differentially uplifted since the end of the Lower Pliocene and filled by the Middle to Upper Pliocene 'Ortovero clays' and by the 'Montevilla conglomerates'. The 'Ortovero clays' are formed by offshore marls and clays deposited probably at depths between 400 and $500 \mathrm{~m}$ (Gianmarino 1984), whereas the 'Montevilla conglomerates' are composed of bedded gravelly deposits associated to sandstones related to several deltaic systems. Their thickness varies from 200 to $400 \mathrm{~m}$. The whole sequence is interpreted to represent the tectonic reactivation of the Ligurian Basin, following rotation of the Corso-Sardinia block and sudden subsidence of the continental margin, followed by a gradual drowning. A phase of uplift of the margin terminated the Pliocene deposition in the area. This phase of uplift allowed a marineforced regression, a new erosive phase, which again affected the Messinian paleo-canyons, reorganization of inland catchments and deposition of deltaic facies. The altitude of the Pliocene deposits varies from east to west; near the border between Italy and France, they crop out as high as $552 \mathrm{~m}$ a.s.l., whereas near Genova, they crop out around $80 \mathrm{~m}$ a.s.l. The uplift occurred from the Middle-Upper Pliocene to the Lower Pleistocene and was spatially and temporally variable. All Pliocene sediments, deposited between Vado Ligure and Albissola were arranged along narrow grabens striking about $65^{\circ} \mathrm{N}$ (Marini 1984).

\subsection{The study area}

The Pliocene deposits of the Savona area are characterized by fossiliferous gray marls and clays. In the Segno Valley (figure 1), the Pliocene deposits are described as a sequence formed by layers of yellowish silty sand and conglomerate layers with wellrounded clasts of quartz (Marini 1987). Gray marls of unknown thickness, containing few macrofossils, are present at the base of this sequence. Beds $\operatorname{dip} 10^{\circ}-25^{\circ}$ to northeast, which were attributed to syn or post-Pliocene tectonic movements (Fanucci et al 1980; Marini 1984, 1987). Marls are considered to be Lower Pliocene in age (Lorenz 1971), whereas the conglomerates interbedded with siltysandstone layers were attributed to the Middle 


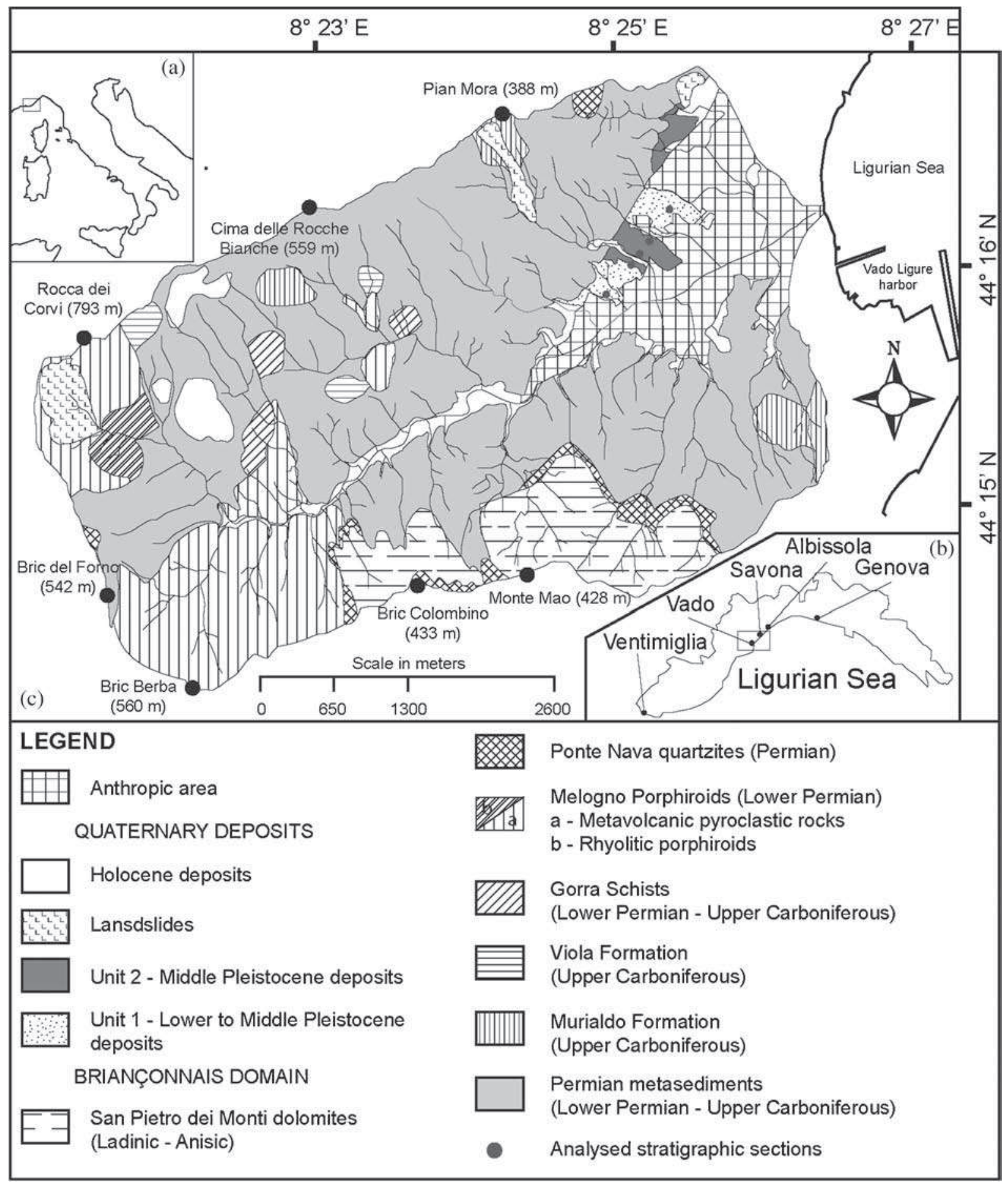

Figure 1. (a) Location of the study area in Italy; (b) location of the study area within the Ligura region; and (c) geological sketch of the Segno River catchment.

Pliocene (Lorenz 1971; Fanucci et al. 1980). A unit made of reddish conglomerate deposited unconformably on the yellowish sands is found at the top of the Pliocene (Upper Pliocene) sequence (Lorenz 1971). This reddish unit was considered as related to the weathering of deposits belonging to the Oligocene Formation (Boni 1984). The relationship between this sequence and other deposits that crop out in the study area is not clear as in the nature of the contact between the marls and the yellowish sands. The deposits of Vado Ligure have many characteristics that differentiate them from coeval deposits cropping out along the Ligurian coast, such as different degrees of weathering, height above the sea level, thickness, cementation and fossiliferous content. Quaternary 
deposits recognized in the study area are represented by the last glacial maximum rudites and conglomerates. In drilling cores, this sedimentary body directly overlies the Middle Pliocene deposits and the Upper Pliocene to Middle Pleistocene sediments are totally absent (Boni 1984; Carobene et al. 2008). Recently, the deposits cropping out near Vado Ligure were dated to the Lower-Middle Pleistocene using in situ produced cosmogenic nuclides (Ciampalini et al. 2015), contributing to a new hypothesis on the evolution of the Ligurian coast during the Pleistocene.

\section{Methodology}

The analysed deposits were partly exposed on land and partly investigated in the related subsurface offshore. In order to map the Plio-Quaternary deposits and landforms, geological and geomorphological surveys at the 1:2000 scale were carried out along the coast. The geological survey was integrated with a detailed facies analysis. Five stratigraphic sections were measured and described in terms of facies associations using the scheme of Miall (1978). Outcrop were described in terms of their lithology, texture, sedimentary structures, colour, geometry and relationships of the beds, fossil content and degree of alteration. Fourteen thin sections were prepared to be examined under polarized microscope to determine early-diagenetic alteration. The micropaleontological content of the sediments was qualitatively observed in 80 samples. The analysis of the paleocurrent data was applied once the component facies were recognized and the facies associations were defined. The paleo-bathymerty and the relationships between the onshore and offshore deposits were determined by studying 51 seismic reflection profiles obtained through the sub-bottom profiler boomer plate and three through the sparker system.

\section{Results}

\subsection{Sedimentology and facies analysis}

Two unconformity bounded stratigraphic units were recognized by combining field observations and facies analysis. The oldest unit (U1) is represented by marine and deltaic deposits, whereas the youngest unit (U2) is composed of continental deposits. A well-expressed subaerial unconformity separates the two units. A large spectrum of lithofacies was distinguished within Pleistocene deposits. Thin sections highlight the presence of a great amount of hematite in the sandy deposits and within the matrix of gravel deposits. From a compositional point of view, gravel deposits are dominated by pure quartz clasts (60-80\%). A brief micropaleontological analysis highlights the complete absence of microfossils. Occasionally, marks of marine benthic foraminifera were observed especially in the facies fb, $\mathrm{fl}$ and fm. Only the HST sediments are described in detail because transgressive shoreface sediments were highly reduced. The absence of the latter may indicate rapidly varying relative sea-level rise (Helland-Hansen and Gjelberg 1994; Longhitano 2008).

A synoptic list of the description of each recognized lithofacies is given below:

- Gh. Description: Poorly sorted, prevalently clastsupported conglomerates organized into horizontally stacked massive beds which are 10-50 cm thick. These conglomerates show a planar or concave erosional base which usually truncates the deltaic underlying facies. Locally, sandy lenses with scattered pebbles can be observed. The clasts consist of sub-rounded to rounded granule to pebble and show a preferential orientation along the short axes.

Interpretation: This facies represents the base of a channel-fill sequence, deposited by a braidedfluvial system.

- Gms. Description: Moderately sorted, clastsupported gravel with interstitial matrix of poorly sorted medium sand and silt with scattered granule or small pebbles (figure 2). The gravel layers appear clino-stratified and they are intercalated to sandy-silty layers ( Fb, Fl, $\mathrm{Sg}$, Shl facies). The clasts consist prevalently of pebble; they are rounded to sub-rounded. The matrix is formed by poorly to well-sorted yellowish medium sand and silt. The gravel layers are generally organized into gently inclined $\left(2^{\circ}-5^{\circ}\right)$ levels in the lower part of the sequence, whereas they reach $30^{\circ}$ in the middle part. The clasts are mostly oriented with the $\mathrm{a}-\mathrm{b}$ axes disposed perpendicular to the dip of the gravel layers. The layers are usually $10-40 \mathrm{~cm}$ thick and show a sharp and slightly erosive base.

Interpretation: This facies has been deposited prevalently along a subaqueous slope, where the flux of sediment was influenced by gravity. The mechanism of transport and deposition is related to avalanches of coarser material (non-cohesive debris flow or debris fall). The geometry of the strata, slightly inclined in the lowermost part and strongly inclined in the middle part of the sequence, reflects the classic geometry of the bottomset and, foreset of a coarse-grained delta (Postma 1990).

- Gmm. Description: Tabular beds of granule to cobble, poorly to moderately sorted gravel. The 
conglomerate is mainly matrix-supported. The beds are massive. The clasts are well-rounded to sub-rounded and they are locally imbricated along the $\mathrm{a}-\mathrm{b}$ axis. The matrix is constituted by yellowish silt to medium sand. The layers are $10-50 \mathrm{~cm}$ thick. The base is sharp and slightly erosive.

Interpretation: The Gmm facies is related to rapid dumping of coarse sediment from turbulent sediment-laden surges of flood water. This mechanism is connected to hyper-concentrated flows after overbank sedimentation (cohesive debris flow). The characteristics are compatible with the topset of a coarse-grained delta during an aggradational phase (Hein and Walker 1977; Ashmore 1982).

- Gp. Description: Mainly horizontal bedded, openframework gravel constituted by well-sorted, clast-supported gravel deposits. The clasts are rounded to sub-angular and, sometimes, present a tabular shape. The grain size is dominated by granule clasts with occasionally scattered small pebbles. The layers present horizontal bedding and inverse grading or are structureless. The clasts are mostly imbricated along the main axis. The matrix is formed by medium-to-coarse sand. Rare marks of bivalves and gastropods scattered within the deposit have been found. The base of this gravel layer is slightly erosive. The thickness of this facies varies between 15 and $40 \mathrm{~cm}$.

Interpretation: The sedimentological characteristics of this facies suggest beach-face deposits of a reflective wave-dominated shoreline (Massari and Parea 1988; Bluck 1999; Ilgar and Nemec 2005). In this environment, the swash and backwash traction is dominant, allowing the variable imbrications of clasts.

- Sc. Description: Cross- and plane-stratified, coarse to medium sands, organized in $20-50 \mathrm{~cm}$ thick beds. The sand appears yellowish and contains organic material remains and rare silty lenses. Occasionally, traces of plant roots have been observed. This facies shows a fining upward trend.

Interpretation: This facies represents the bedload deposits of an active river channel and is associated to the Gh facies described before.

- Sm. Description: The facies $\mathrm{Sm}$ is composed by medium to coarse, massive, poorly sorted sand (figure 2). Locally, within this facies, planeparallel lamination highlighted by the accumulation of organic material has been observed. The sand appears yellowish to brownish. Several wellrounded clasts with grain size from granules to pebbles are scattered within the sand. Rare mud clasts have been observed. This facies presents trace of intense bioturbation and water-escape structures. The Sm facies is often in association with the Gmm facies. Locally, this facies is constituted by a medium-to-coarse sand, very rich in quartz with scattered pebbles of quartz. The thickness of the facies Sm varies between 5 and $45 \mathrm{~cm}$.

Interpretation: The characteristics of this facies are compatible with tractional processes, formed under the action of the waves, extremely homogenized by syn-depositional bioturbations and, subsequently, by the water-escape structures. The latter evidence combined with the presence of organic material mixed to the coarse fraction suggests a rapid rate of sedimentation (Hwang and Chough 1990). Facies Sm has topset geometry typical of the topset section of a coarsegrained delta (Mortimer et al. 2005).

- Sh. Description: 5-30 cm thick tabular sheets of medium sand with fine pebble, showing horizontal lamination. Sheet layers show gradational interstratal contacts and sometimes contain isolated large clasts $(>3 \mathrm{~cm})$ showing a preferential orientation with the a-axis normal to the direction of the paleoflow. The colour varies between yellowish and brownish. The deposits contain rare marks of marine bivalve shells. The base of this facies is planar and non-erosional.

Interpretation: This facies has been deposited through a rapid deposition by sandy hyperconcentrated flood flows (Smith 1974) or shallow fluctuating sheet flows (Maizels 1993). These processes are common in the delta-front.

- Sg. Description: Normal graded and massive coarse sand with scattered clasts granule to pebble in size (figure 2). The clasts are wellrounded to moderately rounded. The sand appears orange or red with grey speckling. This facies appears locally structureless. The base of the $\mathrm{Sg}$ facies is usually planar and non-erosional but occasionally appears wavy. The thickness of this facies varies between 2.5 and $15 \mathrm{~cm}$.

Interpretation: Slipface processes, typical of the slope depositional environment, allow the deposition of this facies. Normal grading indicates turbidity currents (high- or low-density) (Bouma 1962; Nemec and Steel 1984) or choesive sediment gravity flows where the current energy decreases (Walker and Plint 1992)

- Shl. Description: This facies, as the facies Sh, shows a horizontal lamination, but in contrast to Sh, presents a normal gradation. The pebbles are located at the slightly erosive base and are not scattered within the sediment. Facies Shl is 


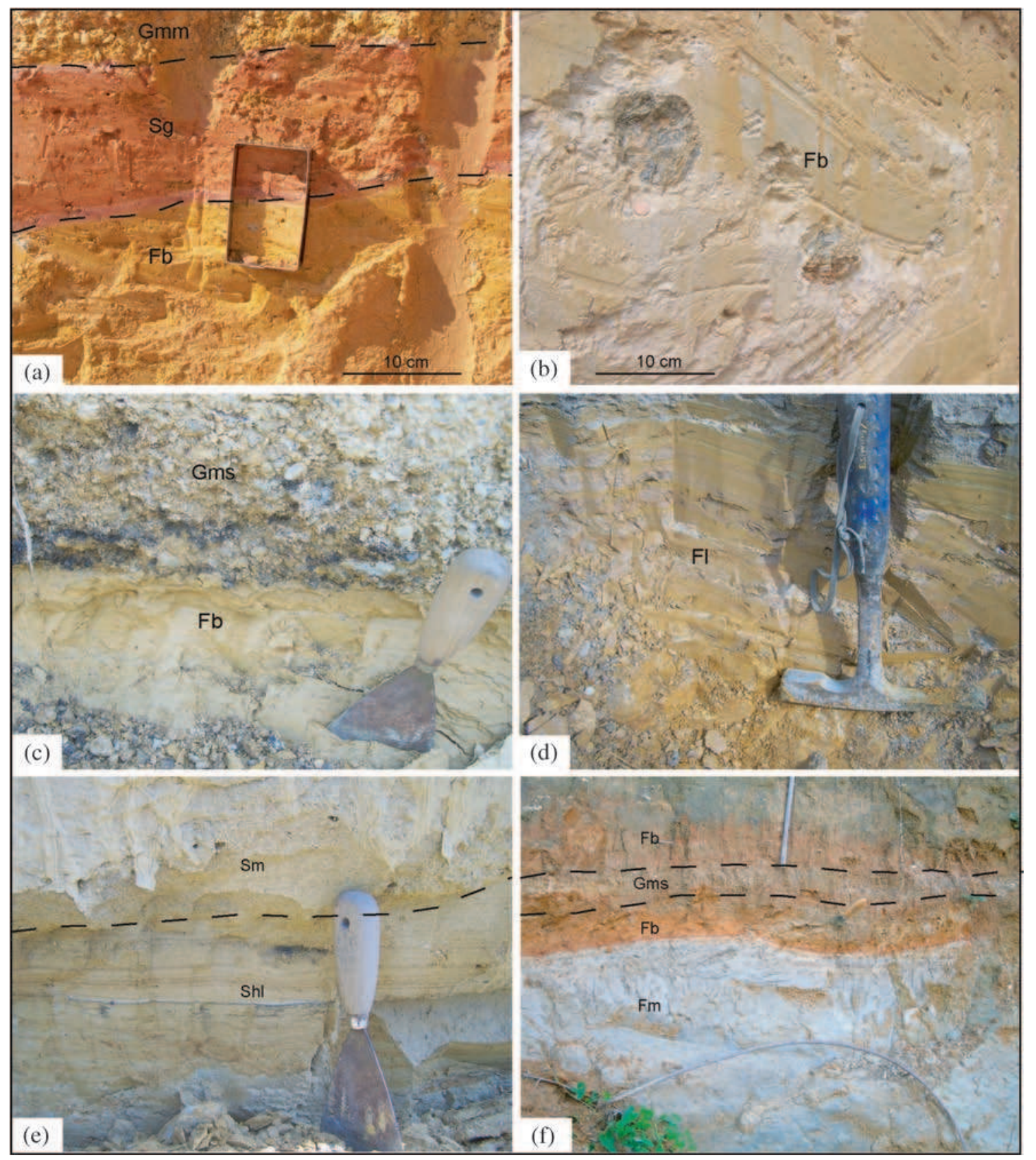

Figure 2. Some examples of the described facies.

composed mainly by moderately sorted, yellowish, medium to coarse sand. Marks of bivalve and gastropod shells have been occasionally observed. This facies is $3-30 \mathrm{~cm}$ thick and shows a planar and non-erosional base.

Interpretation: This facies completes the sandy facies referable to the delta foreset. In particular, facies Shl has been interpreted as traction carpet generated under the action of unidirectional currents flowing perpendicular to the paleo-shoreline. The horizontal lamination can be related to the upper flow regime conditions due to the fluctuation in flow strength (Collinson et al. 2006).
- Fb. Description: Massive yellowish to reddish silt and silty clay containing rare lenses of fine-grained sand (figure 2). Many well-rounded clasts granule to boulder in size are scattered within the silty structureless deposit. The lack of internal structure is probably due to the bioturbation. Several marks of bivalves and marine gastropods have been recognized. The thickness of this facies varies between 8 and $60 \mathrm{~cm}$.

Interpretation: This facies records deposition in the lowermost part of the delta slope, near the transition to the pro-delta zone. The silty portion results from the fallout deposition of suspended fine 
material, after a gravity-generated turbidity current. The presence of pebbles and boulders immersed in the silt is related to isolated slides of coarser material during flash-flows.

- Fl. Description: Laminated silt and muddy silt characterized by flat lamination, small current ripple, lenticular and wavy bedding. Marks of bivalve and gastropod shells have been found, especially, in the silty portion. Occasionally granule to pebble clasts have been recognized within this facies. Usually, the silty portion is yellowish or orange, whereas the muddy portion appears grey. The thickness of this facies varies between 5 and $50 \mathrm{~cm}$.

Interpretation: This facies has been deposited below storm-wave base. The silty portion reflects the delta influence, whereas the muddy portion results from fallout deposition of suspended, very fine material during a fair-weather period. The small current ripples suggest deposition during periodic very intense storm events. The lenticular, flaser and wavy bedding are common in delta toe sediments due to fluctuations in sediment supply.

- Fm. Description: Massive grey silty mud (figure 2). This facies contains several marks of bivalve and marine gastropod shells. Facies Fm usually represents the thinnest part of a finingupward sequence and it is overlaid by a coarser facies, which lies on it with sharp and, locally, slightly erosive base. Several thin lenses of pollen have been locally observed. The thickness of this facies varies between 8 and $120 \mathrm{~cm}$.

Interpretation: Facies Fm represents the deepest facies recognized within the study area and can be related to pro-delta depositional processes. In particular, Fm facies corresponds to a hemipelagic sedimentation with very rare landderived or slope-derived sediments input.

\subsection{Facies associations}

The described facies were grouped in order to identify the facies associations typical of different depositional environments. On the basis of the facies analysis and geometry (figure 3 ) of the recognized lithosomes, four facies associations were identified and related to their respective geometric zones: topset, foreset, bottomset and offshoretransition which are typical of the Gilbert-type fan deltas. This tripartite association, however, is also used to describe coarse-grained deltas (Falk and Dorsey 1998; Nemec 1990; Postma 1990; Uličný 2001; Longhitano 2008; Backert et al. 2010). In this work, a modified model for the description of Gilbert deltas proposed by Longhitano (2008) was used combining the described facies associations.

\subsubsection{Topset facies association}

The topset facies association represents the shallowest depositional environments recognized in the analysed sections. This association is formed by Gmm, Gp, Gh, Sm and Sc facies related by fluvial and shallow marine environments (Bridge 2003). The continental portion is represented by tabular gravel facies ( $\mathrm{Gmm}$ and subordinately Gms) but the channel's morphology was occasionally observed (Gh, Sc). The Gh facies characterized by rare channel fill deposits corresponds to the distal portion of the feeder system constituted by the final part of the channels and by stream-channelized flow transport (Hein and Walker 1977). The Gmm facies corresponds to less confined conditions where sheet flood and debris flow processes are favoured (Marr et al. 2000). The transitional facies are represented by the alternation between the facies Gp and Sm (or rarely Sh), which are typical of coarsegrained mouth bar in wave-dominated shorelines (Ilgar and Nemec 2005; Bressan et al. 2013). The shallow sediments were deposited in the area where the wave action reworked and redistributed the sediments fed by the fluvial system (Massari and Parea 1988; Bluck 1999). The strata belonging to this facies association are characterized by tabular geometry and are located in the topmost part of the studied sections.

\subsubsection{Foreset facies association}

The foreset facies association is the thickest (around $30 \mathrm{~m}$ ) recognized in the study area. This association is characterized by inclined strata dipping at an angle between $23^{\circ}$ and $30^{\circ}$ and it includes facies Gms, Sh, Sg, Shl and occasionally $\mathrm{Gmm}$ and $\mathrm{Fb}$. Gravitational processes as debris flow and sandy hyper-concentrated flood flows dominate this facies association. The paleo-slope angle decrease basinward becoming nearly tangential at the boundary with the bottomset. Matrixrich gravel beds were generated by cohesive and non-cohesive mass flow (e.g., Colella et al. 1987; Prior and Bornhold 1988), whereas clast-supported gravel beds are interpreted as avalanche grain flow or traction carpets (Massari 1996). Rare scours were observed in the upper part of the delta foreset. They are related to gravity instability and slope failure (Nemec 1990; Uličný 2001).

\subsubsection{Bottomset facies association}

The transition between foreset and bottomset facies associations is highlighted by a decrease in the dip of strata. The bottomset facies association is characterized by tangential to horizontal sandy 


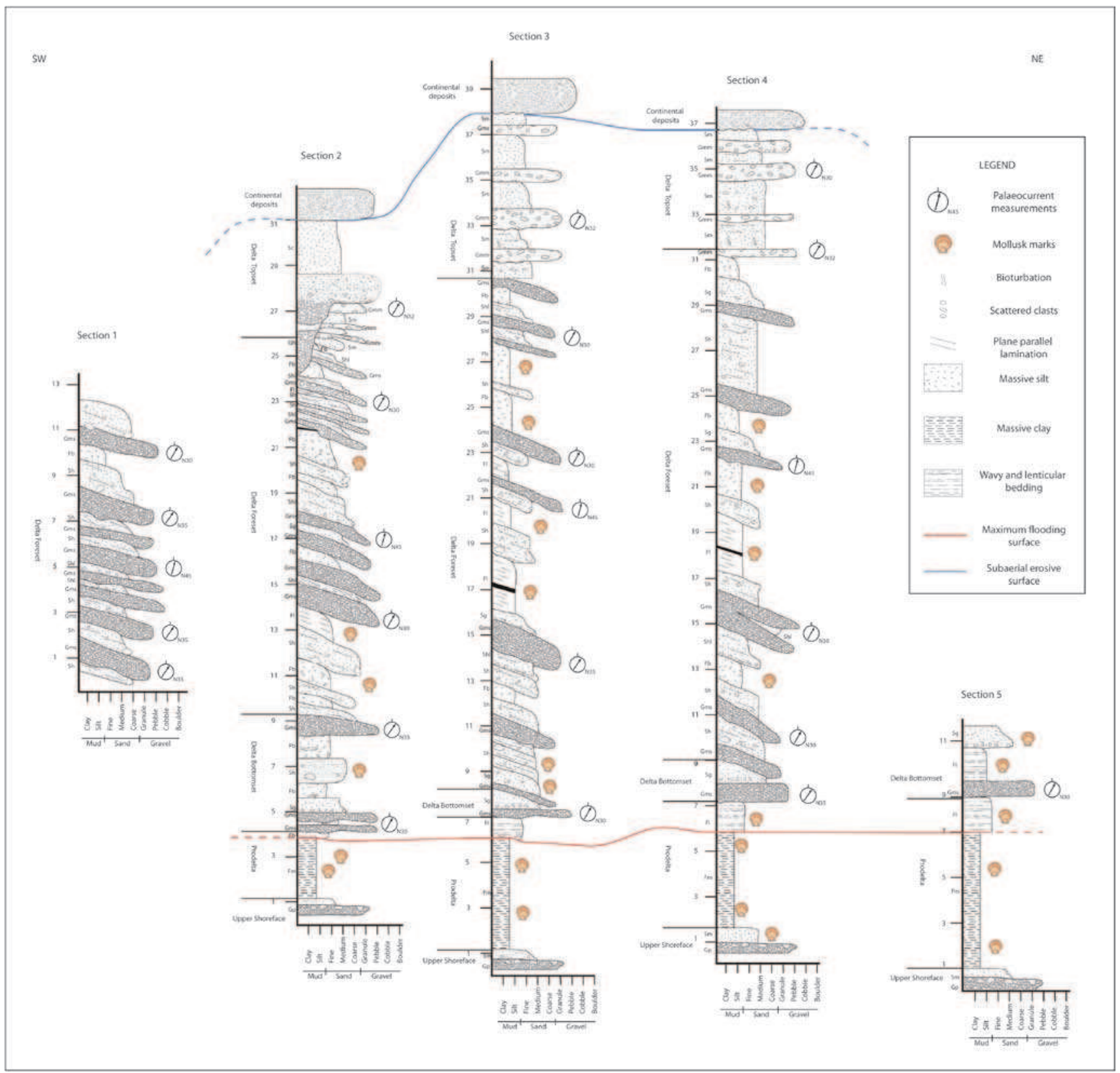

Figure 3. Stratigraphic sections measured in the study area.

to silty beds which gradually refine basinward (Gobo et al. 2014). The most common facies are $\mathrm{Fb}$ and Fl, occasionally facies Shl was observed. A matrix supported gravel layer, $40 \mathrm{~cm}$ thick, was recognized in the delta bottomset and interpreted as a high density turbidity flow generated by a fluvial flood-generated hyperpycnal turbulent flow (Lang and Winsemann 2014; Patruno et al. 2014). The isolated boulders scattered in the silty sediments were interpreted as the result of the failure of coarser material from the upper part of a steep slope (Kim and Chough 2000). The dominance of silty deposits and the presence of wavy-bedding and lenticular-bedding suggest the prevalence of fallout processes in the delta bottomset (Malartre et al. 2004). Flaser bedding and the described gravel layer indicate that tractional processes reached the bottomset of the delta in period characterized by exceptional discharge activity of the feeder system (Postma and Roep 1985; Massari 1996).

\subsubsection{Offshore-transition facies association}

The offshore-transition facies association is scarcely represented in the study area and it corresponds to the facies Fm which is composed of grey structureless massive silty clay deposited as the result of suspension fallout in open-marine setting with intercalations of sandy deposits reworked by wave action. Several moulds of marine bivalves and gastropods were observed in this facies which represents the most observed distal environment. 


\subsubsection{Shoreface facies association}

The presence of this association is very limited in the study area and its thickness is greatly reduced. Amalgamated and/or bioturbated fine- to mediumgrained sandy deposits represent the shoreface facies association. An alternation between massive and laminated beds was locally observed. Usually, the thickness of these layers varies between 0.5 and $1 \mathrm{~m}$. Occasionally, wave ripples were recognized. Very rarely gravel lenses occur and they are characterized by concave-up erosional base. The amalgamated sandy deposits present swales structures. Marks of bivalves and marine gastropods observed by the related species cannot be inferred.

\section{Discussion}

Near Vado Ligure, five stratigraphic sections within Neogene deposits were analysed in order to reconstruct the evolution of the area. These deposits were previously dated using the cosmogenic nuclides $\left({ }^{26} \mathrm{Al}\right.$ and $\left.{ }^{10} \mathrm{Be}\right)$ (Ciampalini et al. 2015). Two allostratigraphic units were recognized. The lower (U1) is constituted by deltaic deposits, whereas the upper (U2) is formed by continental deposits. Within U1, 12 lithofacies were recognized and grouped into four facies associations. Marine environment is testified by the occurrence of marine bivalves and gastropod shells. Unfortunately, the strong alteration dissolved the shells completely, preventing further recognition of the specimen.

\subsection{Sedimentary processes}

The upper part of the deltaic sequence is represented by the topset facies association, which in most cases is incomplete because it was removed by modern erosion. Usually, the delta top is characterized by the delta plain sub-environments (Nichols 2009). This area is occupied by a distributary pattern of channels across the delta top. The typical facies of the delta plain are constituted by the channel fills and subaerial overbank deposited by channel floods which also caused the formation of thin peat layers. The delta topset association has restricted widening and thickness, because of the erosive processes active during the emersion phase. Furthermore, the coarse grain size of the recognized facies (Gmm, Gp, Gh, Sm, Sc) suggest that the delta was fed by a braided river, where gravels were carried directly to the sea and subsequently reworked by the waves action. The horizontally-bedded gravels deposited by hyperconcentrated flows are related to the ephemeral, unconfined streams, involving mass flow and/or debris flow processes. Deposits characterized by well-sorted and rounded grains, clast-supported texture, and open-framework feature were interpreted as gravel beaches. The irregular scoured basal surface of these gravel deposits represent the base of the cusp-and-trough beach morphology (Walker and Plint 1992; Bluck 1999; Longhitano 2008). The parallel-bedded sands are typical of the beachface of a reflective shoreline (Postma 1990; Bluck 1999) affected by swash and backswash traction processes. Bioturbated massive sandy facies with fluid escape structure represents the ancient shoreline. These conditions are typical of a wavedominated shoreline, where the sediments transported by the river are reworked and redistributed by the waves action (Ilgar and Nemec 2005). The foreset facies association is the dominant feature of the deltaic sequence of Vado Ligure, and it is well preserved and completely exposed. The alternation between gravelly and sandy-silty deposits reflects the ephemeral regime of the braided river feeding the delta. The most important processes that affect the deposition in the delta foreset are represented by the gravity-driven mass-transport mechanisms (non-cohesive debris flow, debris fall and turbidity flows) (Postma and Roep 1985). The sandy layers increase their thickness moving seaward, because the hyper-concentrated flows tend to deposit a basal highly concentrated layer, whereas a sandy turbulent flow continue to move along the slope, reaching the deeper areas (Lowe 1982; Nemec 1990; Mulder and Alexander 2001). The debris flow processes are represented by the massive matrix-supported conglomerate deposited by hyper-concentrated flow (Nemec 1990; Uličný 2001). These kinds of processes are common in the upper part of the foreset, where the amount of water is insufficient to rise the turbulence (Dott 1963; Lowe 1988). The extra-size boulders scattered in the sandy-silty layers are due to rolling and avalanching of large rock fragments from the topset of the delta (Prior and Bornhold 1988). The mud in the matrix of the conglomerate and sands suggests that no perfect flow separation at the river mouth occurred; part of the mud was involved in the gravity-flows (cohesive debris flow) which transported downslope the coarse material through high-density flow processes (Lowe 1982; Prior and Bornhold 1988; Falk and Dorsey 1998). The erosive scours created by strong turbulence, related to hydraulic jumps within gravity flows (Uličný 2001) are very rare. These structures are common in the delta slope where the dilution and the reduction in velocity cause the turbulence that erode intensively the surface of the slope (Postma 1984; Uličný 2001). The scours were rapidly filled by the flows, in order to maintain the shape and the dip of the slope (Nemec 1990; Massari 1996). This kind of process is related to low-density gravity currents (non-cohesive debris flow) (Nemec 1990). Near the 
transition between the foreset and the bottomset, the traction carpet drive the depositional processes (Massari 1996). These processes are locally testified by massive gravel layers that are the result of freezing of the base of high-concentrated flows (Nemec and Steel 1984; Nemec 1990), in correspondence of the decreasing of the paleo-slope dip. The delta slope and the foreset facies association do not present trace of influence from the waves action. The bottomset facies association $(\mathrm{Fb}, \mathrm{Fl})$ represents the most distal area affected by the influence of the delta sedimentary supply. Coarse deposits are subordinate to the sandy to muddy facies and record episodic avalanches, debris falls and subaqueous rock fall (Colella et al. 1987; Postma et al. 1988; Nemec 1990; Backert et al. 2010) coming from the slope or from the topset of the delta. The deposition of gravel deposits in the delta bottomset is due to the hydraulic jump caused by the abrupt decrease in flow competence occurring where the slope angle decreases (Porebsky and Steel 2006). Lamination suggests traction flows, whereas normal grading points to a progressive decrease of the flow transport capability. Inverse grading indicates that processes of highconcentrated flow affected the bottomset of the delta (Lowe 1982; Nemec and Steel 1984). The massive silty facies were formed in hemipelagic setting of terrigenous material separated at the river mouth. The offshore-transition is the deepest and most distal paleo-environment recognized within the studied sections. The offshore-transition facies association (Fl, Fm) is dominated by greyish, massive silty mud interpreted as the product of the suspension fallout of the finest-grained material. The muddy silt facies is located landward with respect to the silty mud and is characterized by wavy and lenticular bedding, which are typical sedimentary structure of the offshore-transition environment. This environment is dominated by fallout periods but traction episodes were documented, testifying exceptional inputs from the river system. The coarsest sediments were deposited immediately after a river flood or a turbidity event, which deposited the gravel and sandy portion in the foreset and bottomset, whereas the mud and silt reached the offshore-transition where they were deposited through fallout processes. At the river mouth and at the boundary between foreset and bottomset, sediment segregation is caused by the density difference between the inflowing water and the sea water (Bates 1953; Colella et al. 1987) or by the difference in the inclination of the slope. The finest sediments are transported basinward if the density of the inflowing water is equal (homopycnal flow) or less dense (hypopycnal flow) than the sea water. In the second case, the inflowing water forms a jet flow that allows the floating of the mud and silt (sediment plume), whereas the coarsest material will be deposited at the river mouth or in the delta foreset (Bates 1953; Orton and Reading 1993; Bhattacharya and Giosan 2003; Nichols 2009).

\subsection{Depositional architecture of the Vado Ligure Delta}

The foreset facies association is well expressed (20-30 m) with respect to the topset and the bottomset facies associations. The clinoform dips $20^{\circ}-$ $30^{\circ}$ towards NE, parallel to the N30 lineament which divides the Pleistocene deltaic sequence from the rocky bedrock. The whole analysed sequence is consistent with a prograding and aggrading architecture. The prograding part is represented by the foreset portion, whereas the aggrading is constituted by both the upper portion of the foreset and topset as suggested by the strongly inclined and downstepping architecture of the first and by the weak inclined and/or horizontal setting of the second. The downstepping architecture indicates deposition during forced regression. Furthermore, the transition between progradation and aggradation is marked by an increase in grain size of the deposits, by a shallowing upward trend and by a decrease in measured erosion rates (Ciampalini et al. 2015). The limited extension of the deltaic deposits, caused by the strong urbanization of the area, does not allow the observation of the paleo delta from the proximal to distal part of the basin. The characteristics of each depositional environment, recognizable within the deltaic sequence can vary significantly according to the alluvial feeder or distributary system (Dunne and Hempton 1984; McPherson et al. 1987; Nemec and Steel 1988; Orton 1988; Nichols 2009). Furthermore, these environments are affected by the water depth (Etheridge and Wescott 1984) and by the difference in sediment diffusion within the deltaic environment (Prior and Bornhold 1988), as well as by climate, tectonic and physiographic setting (Leeder et al. 1988; Allen and Allen 2005). The most exhaustive classification of deltaic systems was described by Postma (1990), who, considering many factors (water depth, feeder system, morphology and grain size), identified 12 types of deltas. The morphology of a delta and the characteristics of its sections depend not only on the feeder system, but they are also affected by the bathymetries and by the dynamics of the receiving basin (Elliott 1986; Fraser and Suttner 1986). The shallow-water deltas (some tens of meters) are characterized by both gently and steeply inclined delta slope. Another important factor that affects the development of a delta is the sediment-particle 
transport and deposition beyond the mouth bar (Postma 1990). The deltaic sequence cropping out near Vado Ligure cannot be perfectly included in one of 12 major prototypes described by Postma (1990), and it is intermediate between two prototypes. The height of the foreset is determined by the depth of the water in which the delta is building up and ranges from few tens of meters to over $500 \mathrm{~ms}$ (Elliott 1986). Data suggest that the analysed deltaic sequence can be considered as a midway between types A3 and B4 following the delta classification of Postma (1990), thus a shallow water Gilbert type delta. The delta front of a shallow-water delta is dominated by coarse-load deposition and directly affected by the wave action (Postma 1990) as confirmed by the facies Sm. The offshore-transition is dominated by hemipelagic sedimentation. Between the delta front and the offshore-transition, a well-developed delta slope is present. The slope is weakly affected by the wave action, part of it remains under the fair-weather wave-base level. Gravity-driven mass transport of coarse-grained sediment, debris flows and avalanches represent the most common depositional processes active during the period of river flow. These processes allow to classify the study delta as a Gilbert-type delta. In these cases, the sediments come directly from the river mouth or from the reworking of the delta front. Considering the sedimentological characteristics, the type A3 delta seems to best describe the Vado delta. However, type A3 is strongly dominated by coarse-load deposition in the delta topset and foreset, whereas the topset and foreset at Vado are dominated by a sandy bedload, much more type B4. On the whole, the delta of Vado Ligure presents a well-balanced alternation between gravel and sandy deposits; for this reason, we have considered it as a midway between these two types. Both types are deltas commonly formed by feeder systems, which flow into fjords or lakes. Thus, during the deposition of the analysed sequence, the valley of the Segno river was, probably, a fjord or, at least, an embayment as also suggested by the morphology of the substratum. The vertical distribution of the facies associations indicates that the foreset overlaid the bottomset and the topset overlaid the foreset with the whole deltaic sequence overlying the offshoretransition facies. The sequence shows a continuous vertical transition from fully marine conditions at the base, to subaerial conditions at the top testified by the erosion and subsequently deposition of continental deposits. Furthermore, the transition from the base to the top is highlighted by a coarsening-shoaling upward trend, from lower energy conditions of the offshore-transition, dominated by mud and silt, to the high energy setting of the delta topset, where coarser sediments accumulated. This vertical transition is typical of a prograding Gilbert-type delta, where the foreset build out over the bottomset and in turn the foreset is overlain by topset facies (figure 4). The lack of evidences indicating delta front failure suggests that the delta of Vado Ligure is a Gilberttype delta with a moderate or low bedload/totalload ratio. When the ratio is high, the front of the delta builds up faster than the lower part, causing failure (Postma 1984). This is true for the deep water delta, but is also important for the A3 and B4 shallow-water delta where the bedload/totalload ratio could be depth-dependent (Bogen 1983). The resulting framework of the progradation of a Gilbert-type delta resembles a sandwich of steeply dipping mainly gravel deposits between layers of horizontal beds of gravel and sandy-silty deposits.

\subsection{Delta evolution}

The sequence shows an overall regressive from the offshore-transition facies which represents the maximum deepening of the marine facies landward including the maximum flooding surface, to the overlying deltaic sequence. In this sense, the sedimentary body formed by the offshore-transition marine facies represents the transgressive systems tract (TST). The MFS marks the end of the shoreline transgression and divides retrograding strata below from prograding strata above (Zecchin and Catuneanu 2013, 2014). The lower boundary of the offshore-transition facies corresponds to the maximum regressive surface. In the Vado delta, the TST is highlighted by a fining-deepening upward sequence and by the onlap contact of the offshoretransition facies on the pre-Pleistocene basement. A good preservation of the TST is favoured by a high rate of base-level rise, sediment supply, weak transgressive ravinement erosion, deep water-basin and shallow topographic gradient (Lobo et al. 2001; Catuneanu 2006). The delta of Vado Ligure accumulated in shallow water with a steep gradient and the preservation of the TST is probably due to its geographical position and/or by the high rate of sediment supply (Ciampalini et al. 2015). The delta is placed at the end of the paleo valley of the Segno River, which should have had a similar position to the present Segno river valley, only shifted landward. The ancient valley of the Segno River was, probably, an embayment or a fjord where the delta was protected, at least partly, from the wave action. The foreset and the topset associations represent the highstand systems tract (HST), formed during the late stage of base-level rise, when the rate of rise dropped below the accumulation rate, generating a regression of the shoreline (Catuneanu 2006). The HST is bounded by the maximum flooding surface at the base and by a subaerial erosive 


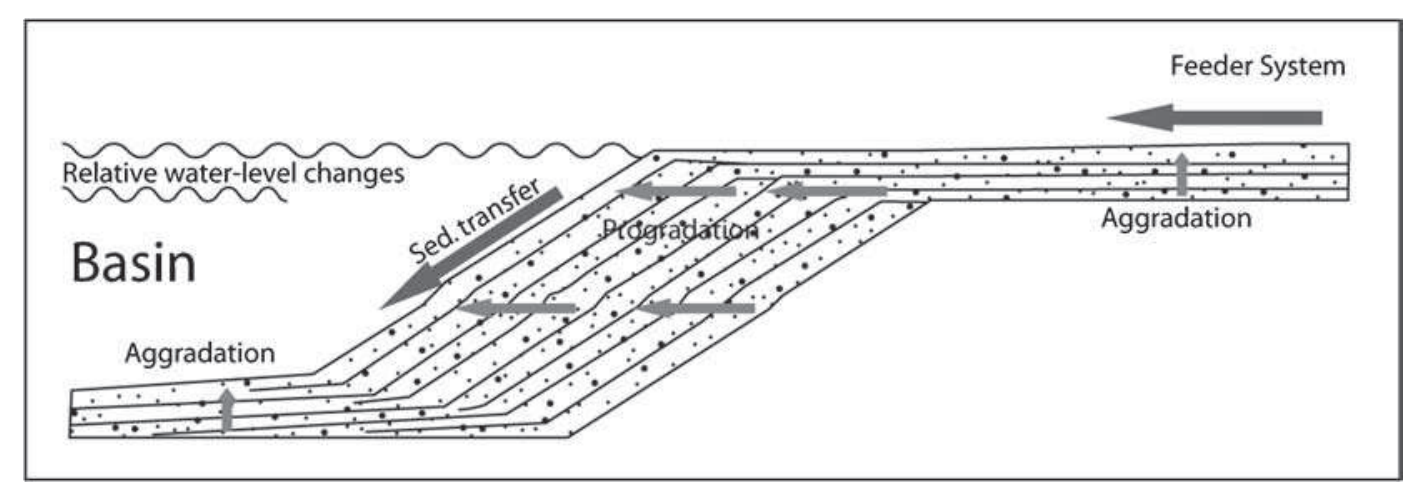

Figure 4. Schematic summary of the development of a Gilbert-type delta (modified after Nemec 1990).

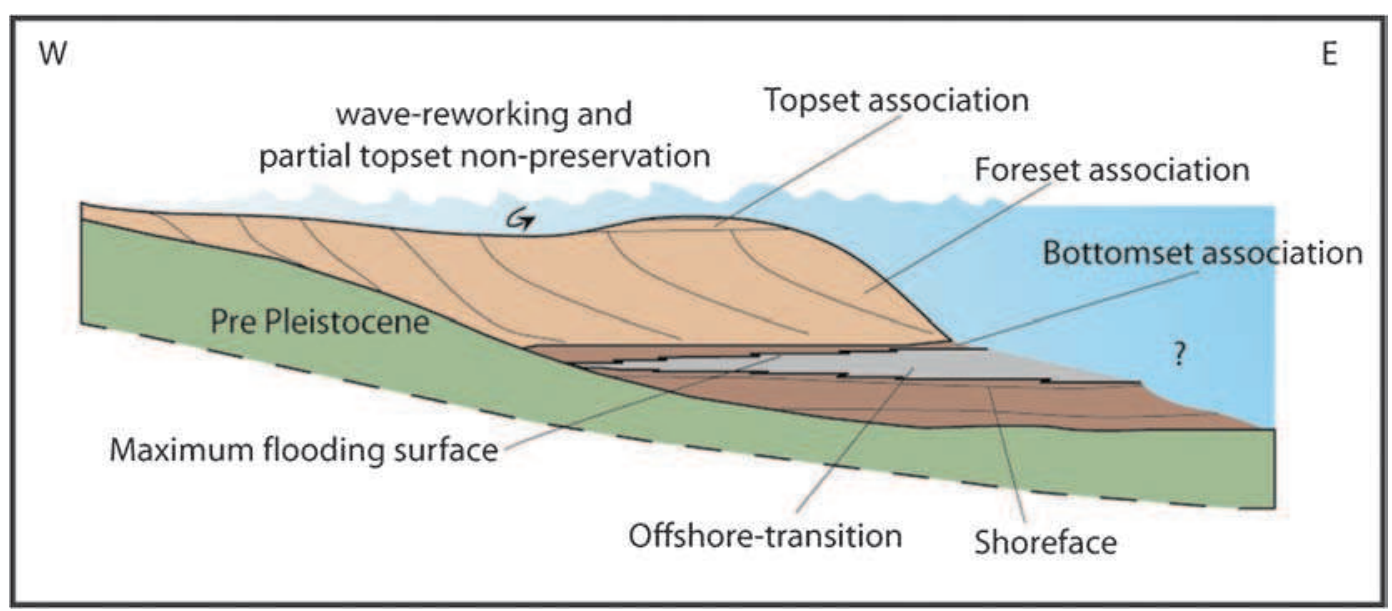

Figure 5. Interpretation of the Gilbert-type delta sequence adapted to the Vado Ligure stratigraphic sections (not drawn to scale).

surface at the top. This systems tract was characterized by the progradation of the deltaic facies, downlapping onto the MFS (figure 5). The deltaic HST deposits tend to be affected by fluvial incision during the subsequent base-level fall. The unconformity at the top of the Vado Ligure deltaic sequence is a clear example of an erosive surface caused by fluvial incision and represents the boundary between $\mathrm{U} 1$ and 2 (figure 6 ).

Many small fluvial systems incised the deltaic sequence, during the relative sea-level fall, form small, incised valleys perpendicular to the coast. Seaward, the unconformity is not recognizable because the deltaic sequence was reworked and superposed by younger (Holocene) unconformity surfaces or removed by human activity. Five boreholes analysed in the Vado coastal plain indicate that the studied Pleistocene deltaic deposits are not present in the subsurface. On the Pliocene mud lies, in unconformity, an Holocene deltaic sequence (Carobene et al. 2008). The subsurface data suggest that the present Vado plain represents the most landward portion of the marine platform on land and that it was completely eroded or bypassed by sediments during both the HST and the FSST. The phase of fluvial incision began when the sealevel fell below the delta front. Usually, the incision is of limited extent along dip and is restricted to the highstand sedimentary prism where the forefront is steeper than the fluvial-graded profile or in presence of structural features as a fault scarp (Catuneanu 2006). The latter is the case of the delta of Vado Ligure. The lowstand fan was not recognized. The bypass processes can be favoured by the submarine canyon, which could have captured a considerable amount of sediments nourished by the fluvial system (Covault and Graham 2010; Paull et al. 2013). During FSST, the deltaic environment became a coastal alluvial plain and was affected by subaerial erosion. The petrographic analysis of the thin section revealed that the intense subsequent alteration does not show evidences of pedogenesis, suggesting a brief period of subaerial exposure. Despite the low pedogenesis, the matrix of the gravel layers and the sandy deposits yield a high amount of hematite $\left(\mathrm{Fe}_{2} \mathrm{O}_{3}\right)$. Hematite $\left(\mathrm{Fe}_{2} \mathrm{O}_{3}\right)$ is a mineral that in most cases requires water for its formation, as it usually forms 


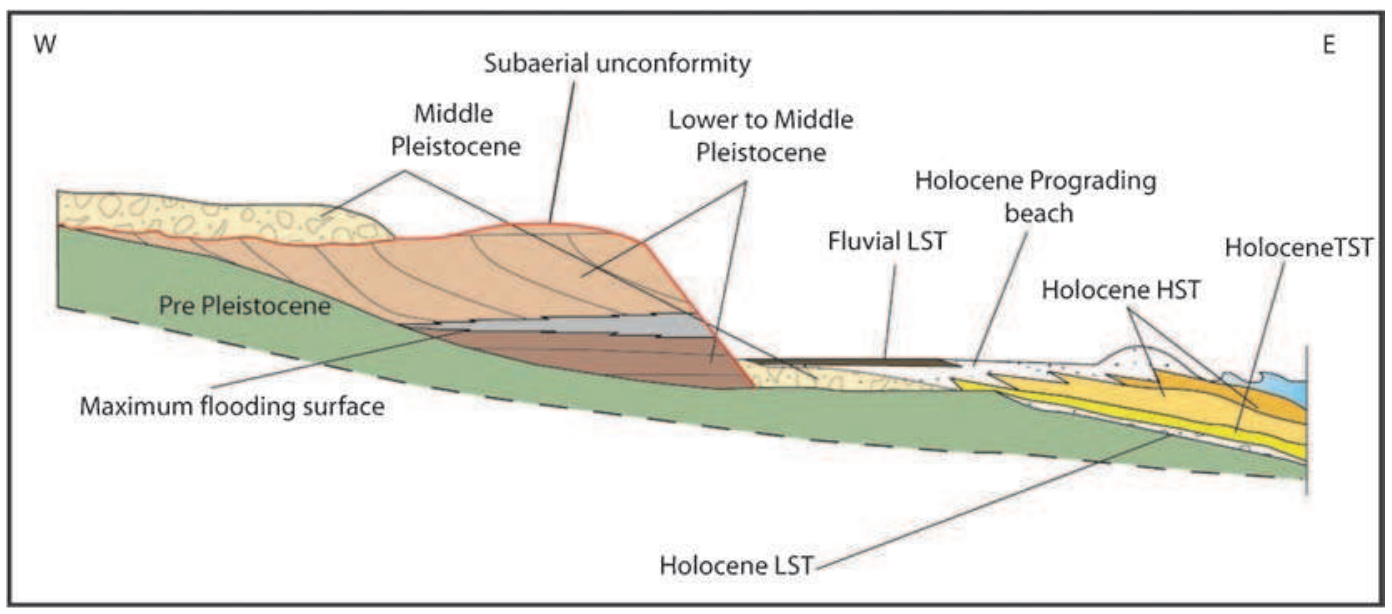

Figure 6. Schematic sketch of the relationships between the Pleistocene and Holocene sequences recognized in the study area.

by subsurface precipitation in flowing water from ions leached away from other minerals by the water (Basberg et al. 1998; Busigny and Dauphas 2007; Abrajevitch et al. 2009). The presence of hematite within the deltaic deposits of Vado suggests that after the sea-level fall, the deltaic sediments hosted a water table fed by $\mathrm{O}_{2}$-rich meteoric water, which oxidized the Fe present in the sediments. The high concentrations of quartz clasts is due to the same alteration processes that generated the accumulation of hematite. The secondary alteration leached all the carbonates present in the deposits as highlighted by both the absence of shells of macro- and micro-fossils and the presence of their marks. The paleocurrent analysis suggests that the main direction of the deltaic deposits had remained constant through the whole sequence and that the paleo-delta flowed with a N30-N35 direction. This direction was measured in the proximity of the slope where the deltaic deposits are in contact with the pre-Neogene substratum. The paleo-Segno catchment was, probably, similar to the present one and the direction of the flow in the central part of the delta should be around N45.

\section{Conclusions}

A reconstruction of the Lower to Middle Pleistocene evolution of a portion of coastal zone of Liguria (Vado Ligure), using sedimentological and stratigraphical approach, combined with new and existing data from boreholes and seismic stratigraphy is proposed. The major conclusions derived from this study are:

- Two different stratigraphic units have been recognized within a sedimentary sequence previously dated at Lower to Middle Pliocene. The lower unit U1 is composed by deltaic and marine deposits, whereas the upper unit U2 is constituted by continental deposits. The two units are divided by a subaerial unconformity.

- Within U1, five facies associations have been detected: topset, foreset, bottomset, shoreface and offshore-transition. They represent a shallowwater, coarse-grained Gilbert type delta. The evolution in time and space of the facies associations shows a classic evolution of a prograding delta related to the sea level variations. The study of the stratigraphic sections allows to detect, within the sequence, the TST which correspond to the maximum deepening of the marine facies landward. This system tract is bounded at its roof by the maximum flooding surface. The TST was replaced by the HST developed during the progradation of the delta. The TST corresponds to a relative-sea-level rise higher than the sediment volume input. The end of the HST was characterized by a high sea-level stand and by a high sedimentary supply, which allowed the aggradation of the delta. The subsequent sea-level fall aimed the emersion of the deltaic sequence and the formation of a subaerial unconformity.

- The evolution of the deltaic sequence occurred between the Lower and the Middle Pleistocene.

- Sedimentary structures have been used to describe the main depositional processes which aimed at the formation of the Vado Ligure delta. In particular, the delta topset is dominated by channel deposits, probably related to a small braided fluvial system. Foreset facies are characterized by the presence of gravitational processes which affect the delta slope, sandy hyper-concentrated flows and cohesive and noncohesive mass flow. The delta bottomset is dominated by fallout processes but, occasionally, it can be interesected by high density turbidity flows. 
- The Ligurian coast is strongly affected by tectonics and eustasy since the Neogene. Separating the influence of tectonics from eustasy is very difficult especially in ancient deposits. During sealevel fall, a part of the Vado Ligure basin margin and the delta were exposed. At this stage, fluvial incision, fluvial bypass and weathering occurred. Fluvial incision formed several small incised valley in the deltaic sediments as a consequence of the relative sea-level fall below the shelf edge. The incised valley were filled by very coarse alluvial fan deposits formed in consequence of an uplift phase which marked the renewal of the uplift of the chain. Furthermore, the absence of synsedimentary faults and slumps suggests a scarce influence of tectonics which can be represented by a weak subsidence of the hanging wall.

- The Lower Pleistocene deposits are welldocumented in the central (Sarti et al. 2007; Ciampalini et al. 2011 and reference therein) and southern Italy (Longhitano 2008 and reference therein), whereas they are not studied in northern margin of the Mediterranean Sea. This study represents an attempt to describe the Lower Pleistocene deposits along the northern edge of the Mediterranean Sea where they have been never pointed before.

\section{References}

Abrajevitch A, Van der Voo R and Rea D K 2009 Variation in relative abundances of ghoetite and hematite in Bengal fan sediments: Climatic vs. diagenetic signals; Mar. Geol. 267 191-206.

Allen P and Allen J R 2005 Basin analysis: Principles and applications; 2nd edn, Blackwell Publishing, 560p.

Ambrosetti P, Carboni M G, Conti M A, Costantini A, Esu D, Gandin A, Girotti O, Lazzarotto A, Mazzanti R, Nicosia U, Parisi G and Sandrelli F 1979 Evoluzione paleogeografica e tettonica nei bacini Tosco-Umbro-Laziali nel Pliocene e nel Pleistocene inferiore; Mem. Soc. Geol. It. 19 573-580.

Ashmore P E 1982 Laboratory modeling of gravel braided stream morphology; Earth Surf. Process. Landf. $\mathbf{7}$ 201-225.

Backert N, Ford M and Malartre F 2010 Architecture and sedimentology of the Kerinitis Gilbert-type fan delta. Corinth Reef, Greece; Sedimentology 57 543-586.

Bardaji T, Dabrio C J, Goy J L, Somoza L and Zazo C 1990 Pleistocene fan deltas in southern Iberian peninsula: Sedimentary control and sea-level change; In: Coarse grained deltas (eds) Colella A and Prior D B, Int. Assoc. Sedim. Spec. Publ. 10 129-154.

Basberg L, Banks D and Sǽther O M 1998 Redox processes in groundwater impacted by landfill leachate; Aquatic Geochemestry 4 253-272.

Bates C C 1953 Rational theory of delta formation; Bull. Am. Assoc. Petrol. Geol. 37 2119-2162.

Bhattacharya J P and Giosan L 2003 Wave-influenced deltas: Geomorphological implications for facies reconstruction; Sedimentology 50 187-210.
Bluck B J 1999 Clast assemblages, bed-forms and structure in gravel beaches; Trans. Roy. Soc. Edinb. Earth Sci. 89 $291-332$.

Bogen J 1983 Morphology and sedimentology of deltas in fjord valleys lake; Sedim. Geol. 36 245-267.

Boni A 1984 Il Pliocene al margine delle Alpi Liguri; Mem. Soc. Geol. It. 28 114-125.

Bossio A, Costantini A, Lazzarotto A, Liotta D, Mazzanti R, Mazzei R, Salvatorini G and Sandrelli F 1993 Rassegna sulle conoscenze del Neoautoctono Toscano; Mem. Soc. Geol. It. 49 17-98.

Bouma A H 1962 Sedimentology of some Flysch deposits: A graphic approach to facies interpretation; Elsevier, Amsterdam, 168p.

Breda A, Mellere D and Massari F 2007 Facies and processes in a Gilbert-delta-filled incised valley (Pliocene of Ventimiglia, NW Italy); Sedim. Geol. 200 31-55.

Bressan G S, Kietzmann D A and Palma R M 2013 Facies analysis of a Toarcian-Bajocian shallow marine/coastal succession (Bardas Blancas Formation) in northern Newuén Basin, Mendoza province, Argentina; J. South Am. Earth Sci. 43 112-126.

Bridge J S 2003 Rivers and floodplains; Blackwell Publishing, Oxford, 491p.

Busigny V and Dauphas N 2007 Tracing paleofluids circulations using iron isotopes: A study of hematite and goethite concretions from the Navajo Sandstones (Utha, USA); Earth Planet. Sci. Lett. 254 272-287.

Cantalamessa G and Di Celma C 2004 Sequence response to syndepositional regional uplift: Insights from highresolution sequence stratigraphy of late Early Pleistocene strata, Periadriatic Basin, central Italy; Sedim. Geol. 164 283-309.

Carobene L, Firpo M and Rovere A 2008 Le variazioni ambientali nell'area di Vado Ligure dal Neolitico ad oggi; $I l$ Quaternario 21(2) 433-456.

Catuneanu O 2006 Principles of Sequence Stratigraphy; Elsevier, 387p.

Champagnac J D, Sue C, Delacou B and Burkhard M 2004 Brittle deformation in the inner NW Alps: From early orogen-parallel extrusion to late orogen-perpendicular collapse; Terra Nova 16 232-242.

Ciampalini A, Consoloni I and Sarti G 2011 Fault array evolution in extensional basins: Insights from statistical analysis of gravel deposits in the Cecina River (Tuscany, Italy); Sedimentology 58(7) 1895-1913.

Ciampalini A, Persano C, Fabel D and Firpo M 2015 Dating Pleistocene deltaic deposits using in-situ ${ }^{26} \mathrm{Al}$ and ${ }^{10} \mathrm{Be}$ cosmogenic nuclides; Quat. Geochron. 28 71-79.

Colalongo M L and Sartoni S 1979 Schema biostratigrafico per il Pliocene e il basso Pleistocene in Italia; Nuovi contributi alla realizzazione della Carta Neotettonica d'Italia $251645-654$.

Colella A, De Boer P L and Nio S D 1987 Sedimentology of a marine intermontane Pleistocene Gilbert-type fan-delta complex in the Crati Basin, Calabria, southern Italy; Sedimentology 34 721-736.

Collinson J, Mountney N and Thompson D 2006 Sedimentary Structures; 3rd edn, Terra Publishing.

Covault J A and Graham S A 2010 Submarine fans at all sealevel stands: Tectonomorphologic and climatic controls on terrigenous sediment delivery to the deep sea; Geology $\mathbf{3 8}$ 939-942.

Di Celma C and Cantalamessa G 2007 Sedimentology and high-frequency sequence stratigraphy of a forearc extensional basin: The Miocene Caleta Herradura Formation, Mejillones peninsula, northern Chile; Sedim. Geol. 198 29-52. 
Di Celma C, Cantalamessa G, Didaskalou P and Lori P 2010 Sedimentology, architecture, and sequence stratigraphy of coarse-grained, submarine canyon fills from the Pleistocene (Gelasian-Calabrian) of the Peri-Adriatic basin, central Italy; Mar. Petrol. Geol. 27 1340-1365.

Doglioni C, Gueguen E, Sàbat F and Fernandez M 1997 The western Mediterranean extensional basins and the Alpine orogen; Terra Nova 9 109-112.

Dott Jr R H 1963 Dynamics of subaqueous gravity depositional processes; Am. Assoc. Petrol. Geol. Bull. 47 104-128.

Dunne L A and Hempton M R 1984 Deltaic sedimentation in the Lake Hazar pull-apart basin, southeastern Turkey; Sedimentology 31 401-412.

Elliott T 1986 Deltas; In: Sedimentary Environments and facies (ed.) Raeding H G, Blackwell, Oxford, 615p.

Etheridge F G and Wescott W A 1984 Tectonic setting, recognition and hydrocarbon reservoir potential of fandelta deposits; In: Sedimentology of gravels and conglomerates (eds) Koster E H and Steel R J, Mem. Can. Soc. Petrol. Geol. 10 217-235.

Falk P D and Dorsey R J 1998 Rapid development of gravelly high-density turbidity currents in marine Gilbert-type fan-deltas, Loreto Basin, Baja California Sur, Mexico; Sedimentology 45 331-350.

Fanucci F, Gianmarino S and Tedeschi D 1980 Il Pliocene della costa e del margine continentale dell'Appennino Ligure in rapporto alla neotettonica; Mem. Soc. Geol. It. 21 259-265.

Fidolini F, Ghinassi M, Aldinucci A, Billi P, Boaga J, Deiana $\mathrm{R}$ and Brivio L 2013 Fault-sourced alluvial fans and their interaction with axial fluvial drainage: An example from the Plio-Pleistocene Upper Valdarno Basin (Tuscany, Italy); Sedim. Geol. 289 19-39.

Fraser G S and Suttner L 1986 Alluvial fans and fan deltas: A guide to exploration for oil and gas; International Human Resources Development Corporation, Boston, 199p.

Gianmarino S 1984 Evoluzione delle Alpi Marittime e le sue relazioni con il Bacino Terziario Piemontese ed il Mar Ligure; Atti Soc. Tosc. Sc. Nat., Mem. Serie A 91 155179.

Gibbard P L and Head M J 2009 The definition of the Quaternary system/era and the Pleistocene series/epoch; Quaternaire 20 125-133.

Gobo K, Ghinassi M and Nemec W 2014 Reciprocal changes in foreset to bottomset facies in a Gilbert-type delta: Response to short-term changes in base level; J. Sedim. Res. 84 1079-1095.

Hein F J and Walker R G 1977 Bar evolution and development of stratification in the gravelly, braided, kicking horse river, British Columbia; Can. J. Earth Sci. 44 562-570.

Helland-Hansen W and Gjelberg J G 1994 Conceptual basis and variability in sequence stratigraphy: A different perspective; Sedim. Geol. 92 31-52.

Hwang I G and Chough S K 1990 The Miocene Chunbuk Formation, southeastern Korea: Marine Gilbert-type fan-delta system; In: Coarse grained deltas (eds) Colella A and Prior D B, Int. Assoc. Sedim. Spec. Publ. 10 235-254.

Ilgar A and Nemec W 2005 Early Miocene lacustrine deposits and sequence stratigraphy of the Ermenek Basin, central Taurides, Turkey; Sedim. Geol. 173 233-275.

Kim J W and Chough S K 2000 A gravel lobe deposit in the prodelta of the Doumsan fan delta (Miocene), SE Korea; Sedim. Geol. 130 183-203.

Lang J and Winsemann J 2014 Lateral and vertical facies relationships of bedforms deposited by aggrading supercritical flows: From cyclic steps to humpback dunes; Sedim. Geol. 296 36-54.
Leeder M R, Ord D M and Collier R 1988 Development of alluvial fans and fan deltas in neotectonic extensional settings: Implication for the interpretation of basin fills; In: Fan deltas: Sedimentology and tectonic settings (eds) Nemec W and Steel R J, pp. 173-185.

Lobo F J, Hernández-Molina F J, Somoza L and Díaz del Río V 2001 The sedimentary record of the post-glacial transgression on the Gulf of Cadiz continental shelf (southwest Spain); Mar. Geol. 178 171-195.

Longhitano S 2008 Sedimentary facies and sequence stratigraphy of coarse-grained Gilbert-type deltas within the Pliocene thrust-top Potenza Basin (southern Apennines, Italy); Sedim. Geol. 210 87-110.

Lopez-Blanco M, Marzo M and Munoz J A 2003 Lowamplitude, synsedimentary folding of a deltaic complex: Roda sandstone (Lower Eocene), south-Pyrenean Foreland Basin; Basin Res. 15 73-96.

Lorenz C R 1971 Observation sur la stratigraphie du Pliocene Ligure: la phase tectonique du Pliocene moyen; C.R. Somm. Soc. Geol. De France 8 441-446.

Lowe D R 1982 Sediment gravity flows: II. Depositional models with special reference to the deposits of high-density turbidity currents; J. Sedim. Petrol. 52 279-297.

Lowe D R 1988 Suspended-load fallout rate as an independent variable in the analysis of current structures; Sedimentology 35 765-776.

Maizels J 1993 Lithofacies variations within sandur deposits: The role of runoff regime, flow dynamics and sediment supply characteristics; Sedim. Geol. 85 299-325.

Malartre F, Ford M and Williams E A 2004 Preliminary biostratigraphy and 3D geometry of the Vouraikos Gilbert-type fan delta, Gulf of Corinth, Greece; Comptes Rendus Geosci. 4-5 269-280.

Marini M 1984 Le deformazioni fragili del Pliocene Ligure; Mem. Soc. Geol. It. 29 157-169.

Marini M 1987 Le deformazioni fragili del Pliocene ligure implicazioni nella geodinamica alpina; Mem. Soc. Geol. It. 29 157-169.

Marr J G, Swenson J B, Paola C and Voller V R 2000 A 2-D diffusion model of fluvial stratigraphy in closed depositional basins; Basin Res. 12 381-398.

Massari F 1996 Upper-flow-regime stratification types on steepface, coarse-grained, Gilbert-type progradational wedges (Pleistocene, southern Italy); J. Sedim. Res. 66 364-375.

Massari F and Parea G C 1988 Progradational gravel beach sequences in a moderate- to high-energy, microtidal marine environment; Sedimentology 35 881-913.

McPherson J G, Shanmugam G and Moiola R J 1987 Fandeltas and braid deltas: Varieties of coarse-grained deltas; Bull. Soc. Geol. Am. 99 331-340.

Miall A D 1978 Lithofacies types and vertical profile models of braided river deposits, a summary; In: Fluvial sedimentology (ed.) Miall A D, Can. Soc. Petrol. Geol. Memoir, Calgary, 5 597-604.

Mortimer E, Gupta S and Cowie P 2005 Clinoform nucleation and growth in coarse-grained deltas, Loreto basin, Baja California Sur, Mexico: A response to episodic accelerations in fault displacement; Basin Res. 17 337359.

Mulder T and Alexander J 2001 The physical character of subaqueous sedimentary density flows and their deposits; Sedimentology 48 269-299.

Nemec W 1990 Aspects of sediment movement on steep delta slopes; In: Coarse grained deltas (eds) Colella A and Prior D B, Int. Assoc. Sedim. Spec. Publ. 10 29-74.

Nemec W and Steel R J 1984 Alluvial and coastal conglomerates: Their significant features and some comments on gravelly mass-flow deposits; In: Sedimentology of Gravels 
and Conglomerates (eds) Koster E H and Steel R J, Memoir 10 1-31.

Nemec W and Steel R J 1988 What is a fan delta and how do we recognize it? In: Fan deltas: Sedimentology and tectonic settings (eds) Nemec W and Steel R J, pp. 3-13.

Nichols G 2009 Sedimentology and stratigraphy; 2nd edn, Wiley-Blackwell edn, Oxford, UK, 431p.

Orton G J 1988 A spectrum of Middle Ordovician fan deltas and braidplain deltas, North Wales: A consequence of varying fluvial clastic input; In: Fan deltas: Sedimentology and tectonic settings (eds) Nemec W and Steel R J, pp. 23-49.

Orton G J and Reading H G 1993 Variability of deltaic processes in terms of sediment supply, with particular emphasis on grain size; Sedimentology 40 475-512.

Ozel E, Ulug A and Pekcetinoz B 2007 Neotectonic aspects of the northern margin of the Adana-Cilicia submarine basin, NE Mediterranean; J. Earth Syst. Sci. 116(2) 113-124.

Patruno S, Hampson G J, Jackson C A L and Dryer T 2014 Clinoform geometry, geomorphology, facies character and stratigraphic architecture of a sand-rich subaqueous delta: Jurassic Sognefjord Formation, offshore Norway; Sedimentology 62 350-388.

Paull C K, Caress D W, Lundsten E, Gwiazda R, Anderson K, McGann M, Conrad J, Edwards B and Summer E J 2013 Anatomy of the La Jolla Submarine Canyon system; offshore southern California; Mar. Geol. 335 16-34.

Porebsky S J and Steel R J 2006 Deltas and sea-level change; J. Sedim. Res. 76 390-403.

Postma G 1984 Slumps and their deposits in fan delta front and slope; Geology 12 27-30.

Postma G 1990 Depositional architecture and facies of river and fan deltas: A synthesis; In: Coarse grained deltas (eds) Colella A and Prior D B, Int. Assoc. Sedim. Spec. Publ. 10 12-27.

Postma G and Roep T B 1985 Resedimented conglomerates in the bottomsets of Gilbert-type gravel deltas; J. Sedim. Petrol. 55(6) 874-885.

Postma G, Nemec W and Kleinspehn K L 1988 Large floating clasts in turbidites: A mechanism for their emplacement; Sedim. Geol. 58 47-61.
Prior D B and Bornhold B D 1988 Submarine morphology and processes of fjord fan deltas and related high-gradient systems: Modern examples from British Columbia; In: Fan deltas: Sedimentology and tectonic settings (eds) Nemec W and Steel R J, Blackie and Son, pp. 125-143.

Rollet N, Déverchère J, Beslier M O, Guennoc P, Réhault J P, Sosson M and Truffert C 2002 Back arc extension, tectonic inheritance, and volcanism in the Ligurian Sea, western Mediterranean; Tectonics 21 1-23.

Sáez A, Anadón P, Herrero M J and Moscariello A 2007 Variable style of transition between Palaeogene fluvial fan and lacustrine systems, southern Pyrenean Foreland, NE Spain; Sedimentology 54 367-390.

Sarti G, Ciampalini A, Consoloni I and Cerrina Feroni A 2007 I depositi del Pleistocene Inferiore della Bassa Val di Cecina (Toscana, Italia): Ricostruzione stratigrafico-deposizionale e proposta di suddivisione in unità allostratigrafiche; Ital. J. Quat. Sci. 20(2) 151-162.

Smith N D 1974 Sedimentology and bar formation in the upper Kicking Horse River, a braided outwash stream; J. Geol. 82 205-223.

Sue C and Tricart P 2002 Widespread normal faulting in the internal western Alps: A new constraint on arc dynamics; J. Geol. Soc. London 159 61-70.

Uličný D 2001 Depositional systems and sequence stratigraphy of coarse-grained deltas in a shallow-marine, strikeslip setting: The Boemian Cretaceous Basin, Czech Republic; Sedimentology 48 599-628.

Vanossi G, Cortesogno L, Galbiati B, Messiga B, Piccardo G and Vannucci R 1984 Geologia delle Alpi Liguri: dati, problemi, ipotesi; Mem. Soc. Geol. It. 28 5-75.

Walker R G and Plint A G 1992 Wave- and storm-dominated shallow marine systems; In: Facies Models - Response to Sea Level Change (eds) Walker R G and James N P, Geol. Assoc. Can. St. John's, pp. 219-238.

Zecchin M and Catuneanu O 2013 Units and bounding surfaces; Marine Petrol. Geol. 39 1-25.

Zecchin M and Catuneanu O 2014 High-resolution sequence stratigraphy of clastic shelves III: Application to reservoir geology; Marine Petrol. Geol., doi: 10.1016/j.marpetgeo.2014.08.025. 